\title{
Development of a TaqMan PCR assay for the detection of Bonamia species
}

\author{
Serge Corbeil ${ }^{1, *}$, Isabelle Arzul ${ }^{2}$, Ben Diggles ${ }^{3}$, Mike Heasman ${ }^{4}$, Bruno Chollet $^{2}$, \\ Franck C. J. Berthe ${ }^{5}$, Mark St. J. Crane ${ }^{1}$ \\ ${ }^{1}$ AAHL Fish Diseases Laboratory, Australian Animal Health Laboratory, CSIRO Livestock Industries, Private Bag 24, \\ Geelong, Victoria 3220, Australia \\ ${ }^{2}$ IFREMER Laboratoire Génétique et Pathologie, Ronce-les-bains BP 133, 17390 La Tremblade, France \\ ${ }^{3}$ DigsFish Services Pty. Ltd., Brisbane, Queensland, Australia \\ ${ }^{4}$ NSW Fisheries, Port Stephens, New South Wales, Australia \\ ${ }^{5}$ Department of Pathology \& Microbiology, Atlantic Veterinary College, University of Prince Edward Island, Canada
}

\begin{abstract}
The development of molecular diagnostic assays with increased sensitivity compared with conventional histological techniques is highly desirable for effective management of bonamiosis in cultured oyster stocks and wild populations. A real-time TaqMan PCR assay was developed for the specific detection of Bonamia species in infected oyster tissues. The TaqMan assay was shown to be significantly more sensitive than histopathology. Although a real-time TaqMan PCR assay is comparable with conventional PCR in terms of sensitivity, it offers the advantages that it is a rapid test and has a very low risk of sample cross-contamination. Furthermore, it can be optimised to quantify the parasite load in samples. The assay detected Bonamia isolates from Australia, New Zealand, Europe, Canada, Chile and the USA and therefore demonstrated genus specificity as tested in this study.
\end{abstract}

KEY WORDS: Bonamia spp. · Real-time TaqMan PCR assay · Oyster

\section{INTRODUCTION}

Diagnosis of infection with Bonamia species is generally achieved by means of histology, a technique currently recommended for screening purposes by the Office International des Epizooties, the World Organisation for Animal Health (OIE 2003). Histology allows topographic assessment of infection by light microscopy through direct visualisation of the parasite, as well as observation of associated lesions. However, this technique is time consuming, requires highly trained staff and has a low sensitivity (Berthe et al. 1999, da Silva \& Villalba 2004). It has been suggested that lowlevel infections of Bonamia spp. may well remain undetected in oyster samples tested by such techniques (Diggles et al. 2003). While low performance of a test can usually be compensated by increasing sample size, the excessive cost associated with the processing of large numbers of samples makes this option impractical. This issue undermines the credibility of Bonamia-free status assessment, especially when environmental conditions are not conducive to clinical expression of the disease or when recent introduction of Bonamia is suspected to have occurred. Clearly, a limited ability to diagnose the presence of these parasites can impede the access of molluscs and their products to international markets. Development of improved tools for surveillance and monitoring is consequently highly desirable.

Three species of Bonamia, B. ostreae (Pichot et al. 1979, Carnegie et al. 2000, Cochennec et al. 2000), B. exitiosa (Dinamani et al. 1987, Hine et al. 2001, Berthe \& Hine 2003) and B. roughleyi (Farley et al. 1988, Cochennec-Laureau et al. 2003) are currently listed by the OIE. A PCR-restriction fragment length polymorphism (PCR-RFLP) assay has been proposed to distinguish between these 3 species (Hine et al. 2001). In addition, Australian flat oysters Ostrea angasi are 
known to harbour Bonamia sp., an endemic isolate that has caused mortalities in the states of Victoria, Tasmania and Western Australia (Hine 1996, CochennecLaureau et al. 2003, Diggles 2003). Other isolates of Bonamia have been reported from $O$. chilensis in Chile (Campalans et al. 2000), Crassostrea ariakensis in North Carolina (Burreson et al. 2004) and O. puelchana in Argentina (Kroeck \& Montes 2005). Taxonomic relationships between these isolates and described species within the genus need to be established.

Although recent developments of PCR-based assays have partially addressed the limitations of histology (Carnegie \& Cochennec-Laureau 2004), real-time PCR (polymerase chain reaction) has the potential to provide rapid and quantitative results. In order to establish an effective diagnostic capability that will help prevent the introduction of exotic Bonamia spp. and to avoid the spread of enzootic isolates, the development of a molecular-based diagnostic assay that allows rapid, reliable and sensitive detection of Bonamia spp. is required. This report describes the development of a real-time PCR assay capable of detecting Bonamia isolates with greater sensitivity than currently available methods.

\section{MATERIALS AND METHODS}

Isolates of Bonamia spp. Wild flat oysters Ostrea angasi, used as a source of Bonamia sp.-infected tissue, were collected and fixed in $95 \%$ ethanol, during the course of a survey on the health and genetics of stocks in 5 estuaries on the south coast of New South Wales, Australia (Heasman et al. 2004). European flat oyster $O$. edulis tissues, infected with isolates of $B$. ostreae and fixed in $95 \%$ ethanol, were obtained from France (6 samples) and the Netherlands (2 samples). Four bluff oyster $O$. chilensis tissues, infected with $B$. exitiosa and fixed in $95 \%$ ethanol, were obtained from New Zealand. In addition, DNA prepared from Bonamia-infected oysters $O$. edulis (Canada and USA) and $O$. chilensis (Chile) was included in the study. Furthermore, DNA obtained from related haplosporidians, as well as from Mikrocytos mackini, was included for specificity assessment during test development.

Bonamia DNA extraction. DNA from Bonamiainfected and uninfected oyster tissues (20 mg of gill and heart) was extracted using a QiaAmp DNA mini kit (Qiagen) according to the manufacturer's instructions. DNA bound to minicolumns was eluted and resuspended in a final volume of $100 \mu \mathrm{l}$ of sterile deionised water. Extracted DNA was diluted 1 in 10 (corresponding to approximately $700 \mathrm{ng}^{-1} \mathrm{l}^{-1}$ of total DNA) prior to amplification in the real-time TaqMan PCR assay.
Diagnostic real-time PCR TaqMan assay. TaqMan primers and probe: An ABI Prism 7700 Sequence Detection System and Sequence Detector software Version 1.9 (PE Applied Biosystems) were used for the analysis and storage of data. Primers and probe for the multiplex TaqMan assay were designed using Primer Express software Version 1.5, TaqMan MGB Probe and Primer Design (PE Applied Biosystems). The Bonamia primers and probe were based on the Internal Transcribed Spacer 1 (ITS-1) region of the rRNA operon, a relatively conserved genomic region among Bonamia isolates. Primer and probe sequences were as follows: forward primer (ITS-For): 5'-CCCTGCCCTTTGTACACACC-3'; reverse primer (ITS-Rev): 5'-TCACAAAGCTTCTAAGAACGCG-3'; and 6-carboxyfluorescein (FAM)-labelled probe (minor groove binder/non-fluorescent quencher) (Bon ITS): 6FAM-TTAGGTGGATAAGAGCCGC. The ITS primers were used at a final concentration of $900 \mathrm{nM}$ each. The Applied Biosystems 18S rRNA endogenous control primers and probe were used to validate the DNA extraction procedure from oyster tissues, confirm the integrity of the extracted DNA and determine the absence of PCR inhibitors. The primers were used under limiting conditions at a final concentration of $113 \mathrm{nM}$ each. The ITS FAM probe and the $18 \mathrm{~S}$ control VIC probe were used at final concentrations of 250 and $31 \mathrm{nM}$, respectively. The reactions were carried out in 96-well plates in a $25 \mu \mathrm{l}$ reaction volume containing $12.5 \mu \mathrm{l}$ Universal Master Mix (PE Applied Biosystems). Aliquots $(2 \mu \mathrm{l})$ of each DNA sample were added to the reaction mix, and the following thermal cycling conditions were used: $50^{\circ} \mathrm{C}$ for $2 \mathrm{~min}, 95^{\circ} \mathrm{C}$ for $10 \mathrm{~min}$, followed by 35 cycles of $95^{\circ} \mathrm{C}$ for $15 \mathrm{~s}$ and $63.6^{\circ} \mathrm{C}$ for $1 \mathrm{~min}$. All reactions were repeated 3 times independently to assess the reproducibility of the results. A sample was considered positive when the change in fluorescence normalised reported $\left(\Delta R_{\mathrm{n}}\right)$ of FAM or VIC, relative to that of ROX (internal reference signal), exceeded the arbitrarily set threshold values of 0.05 for FAM and 0.04 for VIC in the log phase of the amplification plots at a cycle threshold $\left(C_{\mathrm{T}}\right)$ value $<35 . C_{\mathrm{T}}$ is defined as the cycle at which a statistically significant increase in fluorescence output above background is detected.

Specificity testing of the TaqMan assay: Oyster tissues used as positive and negative controls were collected from the Merimbula and Narooma estuaries in New South Wales and from Georges Bay on the east coast of Tasmania, respectively. Presence and absence of Bonamia infection was assessed by histology and conventional PCR assays. In order to demonstrate assay specificity, DNA preparations from phylogenetically related organisms such as Haplosporidium nelsoni and $H$. costale were used as negative controls. The 
Table 1. Summary of semi-quantitative scheme for assessing Bonamia infections in Ostrea spp.

\begin{tabular}{|c|c|c|c|}
\hline Host species & $\begin{array}{l}\text { Light infection } \\
\quad \text { Score }=1\end{array}$ & $\begin{array}{l}\text { Moderate infection } \\
\quad \text { Score }=2\end{array}$ & $\begin{array}{l}\text { Heavy infection } \\
\text { Score }=3\end{array}$ \\
\hline \multirow[t]{2}{*}{ O. angasi } & $\begin{array}{c}<10 \text { microcells } \\
\text { per section }\end{array}$ & $\begin{array}{l}10-250 \text { microcells } \\
\text { per section }\end{array}$ & $\begin{array}{c}>250 \text { microcells } \\
\text { per section }\end{array}$ \\
\hline & $\begin{array}{l}\text { 1-2 microcells } \\
\text { per infected } \\
\text { haemocyte }\end{array}$ & $\begin{array}{c}>1 \text { focus of infected } \\
\text { haemocytes per } \\
\text { section }\end{array}$ & $\begin{array}{c}\text { Multiple foci of } \\
\text { infected haemocytes } \\
\text { with }>2 \text { microcells per } \\
\text { infected haemocyte }\end{array}$ \\
\hline O. edulis & $\begin{array}{l}\text { 1-10 microcells } \\
\text { per section }\end{array}$ & $\begin{array}{l}\text { 11-50 microcells } \\
\text { per section }\end{array}$ & $\begin{array}{l}>50 \text { microcells } \\
\text { per section }\end{array}$ \\
\hline
\end{tabular}

using DNA extracted from 44 Ostrea angasi sourced from Australia and 44 O. edulis from Europe, previously graded by conventional histopathology for the presence of Bonamia sp. and $B$. ostreae cells, respectively. Each oyster was shucked at the sampling site, a standard transverse section $(5 \mathrm{~mm}$ thick) was excised (Howard \& Smith 1983) and fixed in either $10 \%$ formalin made with filtered seawater $(O$. angasi) or in Davidson's fixative (O. edulis) (Bell \& Lightner 1988). The samples were then transported to the pathology laboratory, where they were processed

oyster parasite, Mikrocytos mackini, was also used as a specificity control.

Conventional PCR amplification of the rRNA partial 18S gene. The primer pair Bo/Boas, originally described by Cochennec et al. (2000), was used to amplify Bonamia DNA for sequencing purposes, to confirm the presence of Bonamia cells and to confirm the results obtained by the TaqMan assay. In order to obtain sufficient quantities of DNA for sequencing purposes, the PCR was performed a second time on each PCR product. Each PCR was conducted with a total volume of $25 \mu \mathrm{l}$ of reaction mixture containing PCR buffer (10 mM Tris-HCl, pH 9.0, $50 \mathrm{mM} \mathrm{KCl),} 1 \mathrm{mM}$ $\mathrm{MgCl}_{2}, 200 \mu \mathrm{M}$ each of dATP, dGTP, dCTP and dTTP, and $2.5 \mathrm{U}$ Taq DNA polymerase (Promega). In all PCRs, the primers were used at a final concentration of $1 \mu \mathrm{M}$. Aliquots $(2 \mu \mathrm{l})$ of extracted DNA samples were added to $23 \mu \mathrm{l}$ of reaction mixture for the amplification. Thermocycling conditions for the PCR were as follows: $94^{\circ} \mathrm{C}$ for $2 \mathrm{~min}$ (1 cycle), followed by $94^{\circ} \mathrm{C}$ for $1 \mathrm{~min}$, $55^{\circ} \mathrm{C}$ for $1 \mathrm{~min}$ and $72^{\circ} \mathrm{C}$ for $1 \mathrm{~min}$ (40 cycles), followed by $72^{\circ} \mathrm{C}$ for $5 \mathrm{~min}$ ( 1 cycle). The resulting amplicons were resolved by electrophoresis in $2 \%$ agarose gels using $1 \times$ TAE (0.04 M tris-acetate, $0.001 \mathrm{M}$ EDTA) buffer. Gels were stained with ethidium bromide $\left(0.5 \mu \mathrm{g} \mathrm{ml}^{-1}\right)$.

Sequence determination. The Bonamia 18S rRNA 300 bp partial gene sequence was determined by direct sequencing of the PCR product. Sequencing was carried out using an ABI PRISM Ready Reaction Big dye Termination Cycle Sequencing Kit (Perkin-Elmer) and an ABI PRISM Model 377XL DNA sequencer (Sequencing Analysis 3.4.1 software Version 2.6; Perkin-Elmer).

Sensitivity testing. The sensitivity of the TaqMan assay was assessed for histopathological examination using standard techniques (Howard \& Smith 1983).

One section from each oyster, stained with haematoxylin and eosin ( $\mathrm{H} \& \mathrm{E}$ ), was examined for the presence of Bonamia spp. using a light microscope at both low and high magnifications. As no internationally recognised reference scoring method is currently available, 2 different semi-quantitative scoring methods were used by the Australian and French laboratories (Table 1).

Statistical analysis. Data were analysed using ANOVA, multiple range and Kruskal-Wallis tests (The Stat Advisor). Test results showing a value of $\mathrm{p}<0.05$ indicated a significant difference between means at the $95 \%$ confidence level.

\section{RESULTS AND DISCUSSION}

The Bonamia ITS primers and probe designed in this study identified Bonamia DNA specifically; when amplification was performed, a statistically significant

Table 2. Summary of results demonstrating TaqMan assay specificity. Since, for each experiment, the TaqMan assay is performed in triplicate wells, the average cycle threshold $\left(C_{\mathrm{T}}\right)$ value is given. $C_{\mathrm{T}}$ values $\geq 35$ indicate the absence of specific amplification

\begin{tabular}{|c|c|c|c|c|c|}
\hline Sample & $\begin{array}{r}A \\
\text { Expt } 1\end{array}$ & $\begin{array}{l}\text { verage } \\
\text { Expt } 2\end{array}$ & $\begin{array}{l}{ }^{-} \mathrm{T} \\
\text { Expt } 3\end{array}$ & Mean & $\mathrm{SD}$ \\
\hline Uninfected tissue (negative control) & 35.00 & 35.00 & 35.00 & 35.00 & - \\
\hline Mikrocytos mackini & 35.00 & 35.00 & 35.00 & 35.00 & - \\
\hline Haplosporidium nelsoni & 35.00 & 35.00 & 35.00 & 35.00 & - \\
\hline Haplosporidium costale & 35.00 & 35.00 & 35.00 & 35.00 & - \\
\hline Bonamia sp. (NSW, Australia) & 21.69 & 22.44 & 21.74 & 21.96 & 0.42 \\
\hline Bonamia exitiosa (New Zealand) & 23.60 & 23.96 & 23.53 & 23.70 & 0.23 \\
\hline Bonamia ostreae (France) & 16.20 & 16.26 & 16.91 & 16.46 & 0.39 \\
\hline Bonamia ostreae (Netherlands) & 16.12 & 16.28 & 16.32 & 16.24 & 0.10 \\
\hline Bonamia ostreae (BC, Canada) & 28.82 & 29.26 & 28.98 & 29.02 & 0.22 \\
\hline Bonamia ostreae (WA, USA) & 18.82 & 19.54 & 18.69 & 19.02 & 0.45 \\
\hline Bonamia sp. (Chile) & 20.02 & 19.80 & 19.83 & 19.88 & 0.12 \\
\hline
\end{tabular}


Table 3. Ostrea angasi. Comparison of TaqMan assay with histological examination of tissues. Since, for each experiment, the TaqMan assay is performed in duplicate wells, the average $C_{\mathrm{T}}$ value is given. (Note: $C_{\mathrm{T}}$ values $\geq 35$ indicate the absence of specific amplification.) N: negative; L: low; M: medium

\begin{tabular}{|c|c|c|c|c|c|c|}
\hline $\begin{array}{l}\text { Sample } \\
\text { no. }\end{array}$ & $\begin{array}{r}\text { A } \\
\text { Expt } 1\end{array}$ & $\begin{array}{l}\text { verage } \\
\text { Expt } 2\end{array}$ & $\begin{array}{l}\mathcal{C}_{\mathrm{T}} \\
\text { Expt } 3\end{array}$ & Mean & SD & $\begin{array}{c}\text { Histology } \\
\text { grading }\end{array}$ \\
\hline 1 & 27.71 & 28.22 & 29.22 & 28.38 & 0.76 & $\mathrm{~N}$ \\
\hline 2 & 26.05 & 26.77 & 27.75 & 26.86 & 0.85 & $\mathrm{~N}$ \\
\hline 3 & 30.35 & 30.38 & 32.76 & 31.16 & 1.38 & $\mathrm{~N}$ \\
\hline 4 & 25.65 & 25.75 & 26.81 & 26.07 & 0.64 & $\mathrm{~N}$ \\
\hline 5 & 22.75 & 22.52 & 23.18 & 22.81 & 0.33 & $\mathrm{~N}$ \\
\hline 6 & 28.70 & 28.35 & 29.29 & 28.78 & 0.47 & $\mathrm{~N}$ \\
\hline 7 & 27.75 & 28.20 & 28.88 & 28.27 & 0.56 & $\mathrm{~N}$ \\
\hline 8 & 34.85 & 34.50 & 34.71 & 34.68 & 0.17 & $\mathrm{~N}$ \\
\hline 9 & 34.91 & 34.01 & 34.93 & 34.61 & 0.52 & $\mathrm{~N}$ \\
\hline 10 & 32.88 & 31.75 & 32.87 & 32.5 & 0.64 & $\mathrm{~N}$ \\
\hline 11 & 34.81 & 34.17 & 35.00 & 34.66 & 0.43 & $\mathrm{~N}$ \\
\hline 12 & 33.48 & 33.01 & 34.08 & 33.52 & 0.53 & $\mathrm{~N}$ \\
\hline 13 & 32.95 & 32.31 & 33.49 & 32.91 & 0.59 & $\mathrm{~N}$ \\
\hline 14 & 32.5 & 31.88 & 33.03 & 32.47 & 0.57 & $\mathrm{~N}$ \\
\hline 15 & 30.27 & 30.49 & 31.45 & 30.73 & 0.62 & $\mathrm{~N}$ \\
\hline 16 & 28.55 & 28.56 & 29.19 & 28.76 & 0.36 & $\mathrm{~N}$ \\
\hline 17 & 35.00 & 35.00 & 35.00 & 35.00 & - & $\mathrm{N}$ \\
\hline 18 & 32.42 & 32.6 & 33.48 & 32.83 & 0.56 & $\mathrm{~N}$ \\
\hline 19 & 32.22 & 32.97 & 33.17 & 32.78 & 0.50 & $\mathrm{~N}$ \\
\hline 20 & 35.00 & 35.00 & 35.00 & 35.00 & - & $\mathrm{N}$ \\
\hline 21 & 30.27 & 31.23 & 31.77 & 31.08 & 0.77 & $\mathrm{~N}$ \\
\hline 22 & 25.6 .0 & 26.6 & 27.64 & 26.61 & 1.02 & $\mathrm{~N}$ \\
\hline 23 & 28.66 & 28.82 & 30.10 & 29.19 & 0.78 & $\mathrm{~L}$ \\
\hline 24 & 27.75 & 28.26 & 29.38 & 28.46 & 0.83 & L \\
\hline 25 & 24.7 .0 & 25.09 & 26.18 & 25.32 & 0.76 & $\mathrm{~L}$ \\
\hline 26 & 25.19 & 25.11 & 25.87 & 25.39 & 0.41 & L \\
\hline 27 & 23.12 & 22.85 & 23.94 & 23.30 & 0.56 & $\mathrm{~L}$ \\
\hline 28 & 21.22 & 20.89 & 21.84 & 21.31 & 0.48 & $\mathrm{~L}$ \\
\hline 29 & 27.70 & 27.06 & 27.88 & 27.54 & 0.43 & $\mathrm{~L}$ \\
\hline 30 & 28.28 & 27.52 & 28.50 & 28.10 & 0.51 & $\mathrm{~L}$ \\
\hline 31 & 27.40 & 26.67 & 27.66 & 27.24 & 0.51 & L \\
\hline 32 & 32.45 & 32.25 & 33.49 & 32.73 & 0.66 & $\mathrm{~L}$ \\
\hline 33 & 27.97 & 27.81 & 28.95 & 28.24 & 0.61 & $\mathrm{~L}$ \\
\hline 34 & 21.13 & 20.94 & 21.57 & 21.21 & 0.32 & L \\
\hline 35 & 28.58 & 29.22 & 30.29 & 29.36 & 0.86 & $\mathrm{~L}$ \\
\hline 36 & 31.70 & 32.16 & 33.33 & 32.39 & 0.84 & L \\
\hline 37 & 30.81 & 30.96 & 32.32 & 31.36 & 0.83 & $\mathrm{~L}$ \\
\hline 38 & 24.50 & 25.14 & 25.79 & 25.14 & 0.64 & $\mathrm{~L}$ \\
\hline 39 & 26.04 & 25.80 & 27.00 & 26.28 & 0.63 & $\mathrm{M}$ \\
\hline 40 & 21.09 & 20.76 & 22.14 & 21.33 & 0.72 & M \\
\hline 41 & 28.55 & 29.39 & 30.28 & 29.40 & 0.86 & M \\
\hline 42 & 29.53 & 30.27 & 30.88 & 30.22 & 0.67 & M \\
\hline 43 & 24.34 & 25.59 & 26.47 & 25.46 & 1.07 & M \\
\hline 44 & 22.33 & 22.46 & 23.66 & 22.81 & 0.73 & M \\
\hline \multicolumn{7}{|c|}{ Neg. control } \\
\hline & 35.00 & 35.00 & 35.00 & 35.00 & - & - \\
\hline \multicolumn{7}{|c|}{ Pos. control } \\
\hline & 20.95 & 21.14 & 22.36 & 21.48 & 0.76 & - \\
\hline \multicolumn{4}{|c|}{ Prevalence of infection } & $\begin{array}{l}42 / 44 \\
(95 \%)\end{array}$ & & $\begin{array}{l}22 / 44 \\
(50 \%)\end{array}$ \\
\hline
\end{tabular}

increase in fluorescence was recorded in the wells containing DNA from Bonamia isolates, regardless of the geographic origin. On the other hand, no Bonamiaspecific product was amplified from wells containing DNA from either related organisms or uninfected oyster tissue, demonstrating specificity of the assay (Table 2).

The TaqMan assay performed on DNA extracted from Bonamia sp.-infected Ostrea angasi tissues showed that all samples assessed positive by conventional histopathology were also positive by the realtime PCR assay. In addition, out of 22 samples assessed negative by histopathology, 20 yielded positive results using the real-time PCR TaqMan assay (Table 3). The overall prevalence of infection in $O$. angasi, as determined by histopathology and real-time PCR assay, was 50 and $95 \%$, respectively (Table 3 ). In order to confirm the TaqMan assay results, weak positive samples $\left(C_{\mathrm{T}}\right.$ values ranging between 33 and 35) were also amplified by conventional PCR. The resulting amplicons were consequently sequenced and confirmed to be Bonamia specific. With regard to samples from Europe (O. edulis infected with $B$. ostreae), the TaqMan assay could also detect all levels of infection assessed by histopathology (Table 4).

These results are not surprising as it is well known and recognised that $\mathrm{PCR}$ technologies provide a higher level of sensitivity when compared with histopathology. Our data are also consistent with results previously obtained, which show that PCR was more sensitive than the use of heart imprints and histology for the detection of Bonamia ostreae and B. exitiosa (Carnegie et al. 2000, Cochennec et al. 2000, Diggles et al. 2003).

Although the TaqMan assay detected the presence of Bonamia in Ostrea angasi that had been judged 'negative' for the presence of Bonamia by histopathology, no epizootics or large, unexplained mortality events of farmed oysters have been reported from any estuary of southern New South Wales in the last 5 yr. This observation contrasts with reports of flat oyster mortalities that have occurred in other Australian states (Hine 1996). Further investigation would be required to shed light on virulence differences between Australian Bonamia isolates and host-species specificity, as well as epizootiological factors such as the effects of water temperature, oyster density and environmental stressors on Bonamia infections and bonamiosis disease.

With regard to the level of infection in each oyster sample, it is noteworthy that there was an inverse correlation between histology values (negative, low and medium) and $C_{\mathrm{T}}$ values from the TaqMan assays. Samples infected with higher numbers of Bonamia cells were detected more rapidly (low $C_{\mathrm{T}}$ values) than sam- 
ples containing fewer Bonamia cells (high $C_{\mathrm{T}}$ values) (Table 5). Similarly, Ostrea edulis samples containing higher loads of $B$. ostreae showed a smaller average $C_{\mathrm{T}}$ value than those containing a lower number of parasite

Table 4. Ostrea edulis. Comparison of TaqMan assay with histological examination of tissues. Since, for each experiment, the TaqMan assay is performed in duplicate wells, the average $C_{\mathrm{T}}$ value is given. (Note: $C_{\mathrm{T}}$ values $\geq 35$ indicate the absence of specific amplification.) $\mathrm{N}$ : negative; L: low; $\mathrm{M}$ : medium

\begin{tabular}{|c|c|c|c|c|c|c|}
\hline $\begin{array}{l}\text { Sample } \\
\text { no. }\end{array}$ & $\begin{array}{ll}\text { le } & A \\
\text { Expt } & 1\end{array}$ & $\begin{array}{l}\text { verage } \\
\text { Expt } 2\end{array}$ & $\begin{array}{l}C_{\mathrm{T}} \\
\text { Expt } 3\end{array}$ & Mean & $\mathrm{SD}$ & $\begin{array}{c}\text { Histology } \\
\text { grading }\end{array}$ \\
\hline 1 & 34.16 & 34.84 & 34.37 & 34.46 & 0.34 & $\mathrm{~L}$ \\
\hline 2 & 33.80 & 34.22 & 34.76 & 34.26 & 0.48 & $\mathrm{~L}$ \\
\hline 3 & 32.27 & 32.12 & 32.62 & 32.34 & 0.26 & $\mathrm{~L}$ \\
\hline 4 & 32.16 & 32.63 & 32.40 & 32.40 & 0.23 & $\mathrm{~L}$ \\
\hline 5 & 27.66 & 27.75 & 27.88 & 27.76 & 0.11 & $\mathrm{~L}$ \\
\hline 6 & 27.72 & 27.83 & 28.40 & 27.98 & 0.36 & L \\
\hline 7 & 27.07 & 27.10 & 27.64 & 27.27 & 0.32 & $\mathrm{~L}$ \\
\hline 8 & 27.52 & 27.48 & 27.66 & 27.55 & 0.09 & $\mathrm{~L}$ \\
\hline 9 & 30.24 & 30.28 & 29.91 & 30.14 & 0.20 & $\mathrm{~L}$ \\
\hline 10 & 30.20 & 30.43 & 30.16 & 30.26 & 0.15 & $\mathrm{~L}$ \\
\hline 11 & 26.19 & 25.96 & 25.51 & 25.89 & 0.35 & $\mathrm{~L}$ \\
\hline 12 & 26.19 & 26.30 & 25.91 & 26.13 & 0.20 & $\mathrm{~L}$ \\
\hline 13 & 28.64 & 27.68 & 28.51 & 28.28 & 0.52 & $\mathrm{~L}$ \\
\hline 14 & 28.45 & 28.26 & 27.88 & 28.20 & 0.29 & $\mathrm{~L}$ \\
\hline 15 & 21.99 & 22.10 & 22.08 & 22.06 & 0.06 & $\mathrm{~L}$ \\
\hline 16 & 21.99 & 22.05 & 22.04 & 22.03 & 0.03 & $\mathrm{~L}$ \\
\hline 17 & 22.88 & 21.78 & 22.50 & 22.39 & 0.56 & M \\
\hline 18 & 22.76 & 22.26 & 22.43 & 22.48 & 0.25 & M \\
\hline 19 & 27.30 & 27.30 & 27.45 & 27.35 & 0.09 & M \\
\hline 20 & 27.65 & 27.42 & 27.57 & 27.55 & 0.12 & M \\
\hline 21 & 26.24 & 28.49 & 25.92 & 26.88 & 1.40 & M \\
\hline 22 & 26.86 & 26.18 & 26.00 & 26.35 & 0.45 & M \\
\hline 23 & 27.68 & 27.86 & 27.53 & 27.69 & 0.16 & M \\
\hline 24 & 27.35 & 27.49 & 27.60 & 27.48 & 0.12 & M \\
\hline 25 & 24.17 & 24.34 & 24.17 & 24.23 & 0.10 & M \\
\hline 26 & 23.98 & 24.16 & 24.07 & 24.07 & 0.09 & M \\
\hline 27 & 20.36 & 20.45 & 20.40 & 20.40 & 0.05 & M \\
\hline 28 & 20.31 & 20.53 & 20.42 & 20.42 & 0.11 & M \\
\hline 29 & 20.42 & 20.18 & 20.48 & 20.36 & 0.16 & $\mathrm{H}$ \\
\hline 30 & 20.46 & 20.49 & 20.54 & 20.50 & 0.04 & $\mathrm{H}$ \\
\hline 31 & 26.56 & 26.10 & 25.88 & 26.18 & 0.34 & $\mathrm{H}$ \\
\hline 32 & 26.92 & 26.33 & 26.33 & 26.53 & 0.34 & $\mathrm{H}$ \\
\hline 33 & 21.68 & 21.32 & 21.14 & 21.38 & 0.28 & $\mathrm{H}$ \\
\hline 34 & 21.36 & 21.51 & 21.32 & 21.40 & 0.10 & $\mathrm{H}$ \\
\hline 35 & 19.82 & 19.18 & 19.34 & 19.45 & 0.33 & $\mathrm{H}$ \\
\hline 36 & 19.22 & 19.16 & 19.09 & 19.16 & 0.07 & $\mathrm{H}$ \\
\hline 37 & 21.08 & 20.06 & 20.26 & 20.47 & 0.54 & $\mathrm{H}$ \\
\hline 38 & 20.65 & 20.27 & 20.3 & 20.41 & 0.21 & $\mathrm{H}$ \\
\hline 39 & 22.53 & 22.4 & 23.15 & 22.69 & 0.40 & $\mathrm{H}$ \\
\hline 40 & 22.44 & 22.49 & 22.59 & 22.51 & 0.08 & $\mathrm{H}$ \\
\hline 41 & 20.43 & 20.26 & 20.29 & 20.33 & 0.09 & $\mathrm{H}$ \\
\hline 42 & 20.6 & 20.47 & 20.61 & 20.56 & 0.08 & $\mathrm{H}$ \\
\hline 43 & 21.22 & 21.26 & 21.57 & 21.35 & 0.19 & $\mathrm{H}$ \\
\hline 44 & 21.28 & 21.43 & 21.74 & 21.48 & 0.23 & $\mathrm{H}$ \\
\hline \multicolumn{7}{|c|}{ Neg. control } \\
\hline & 35.00 & 35.00 & 35.00 & 35.00 & - & - \\
\hline \multicolumn{7}{|c|}{ Pos. control } \\
\hline & 22.1 & 22.02 & 25.72 & 23.28 & 2.11 & - \\
\hline
\end{tabular}

cells (Table 6). This is to be expected as a higher load of Bonamia cells provides a larger amount of DNA target, hence, allowing the parasites to be detected sooner in the PCR amplification process.

The TaqMan assay presented in this study has the added advantages, compared to more traditional histopathological assays, that it is highly sensitive, specific, rapid and allows high throughput. The cost of running the assay is approximately half the cost of histopathology diagnosis; it provides a more correct assessment of the prevalence of the pathogen and reduces the potential for false 'negatives'. Indeed, many tissue samples assessed as negative by histopathology yielded positive results using the TaqMan assay. In addition, the TaqMan assay presents a very low risk of sample cross-contamination and can be optimised to quantify the parasite load in samples. Also, large numbers of oysters can be nondestructively screened (Carnegie et al. 2000).

However, PCR-based assays have limitations. Inhibitory factors in mollusc tissues may contribute to false negative results. In addition, degraded pathogen DNA may generate positive results where there are no viable parasites. Furthermore, it is noted that light infections may be missed due to the small size of the tissue samples; however, this could have a limited impact, as the infection with Bonamia species is usually systemic, with infectious particles being transported by haemocytes.

Table 5. Ostrea angasi. Comparison of mean $C_{\mathrm{T}}$ values per group of oysters with histological evaluation. Mean $C_{\mathrm{T}}$ values were obtained from the mean values of each histology-graded group presented in Table 3

\begin{tabular}{|lcc|}
\hline Mean $C_{\mathrm{T}}$ & SD & Histology grading \\
\hline $30.93^{\mathrm{a}}$ & 3.41 & Negative \\
$27.27^{\mathrm{b}}$ & 3.50 & Low \\
$25.92^{\mathrm{b}}$ & 3.51 & Medium \\
a Significantly different from other means $(\mathrm{p}<0.01)$ \\
' $\begin{array}{l}\text { bow and medium mean } C_{\mathrm{T}} \text { values are not significantly } \\
\text { different from each other }\end{array}$ \\
\hline
\end{tabular}

Table 6. Ostrea edulis. Comparison of mean $C_{\mathrm{T}}$ values per group of oysters with histological evaluation. Mean $C_{\mathrm{T}}$ values were obtained from the mean values of each histologygraded group presented in Table 4

\begin{tabular}{|lcc|}
\hline Mean $C_{\mathrm{T}}$ & $\mathrm{SD}$ & Histology grading \\
\hline $28.56^{\mathrm{a}}$ & 3.68 & Low \\
$24.77^{\mathrm{a}}$ & 2.81 & Medium \\
$21.55^{\mathrm{a}}$ & 2.09 & Heavy \\
a Significantly different from other means $(\mathrm{p}<0.01)$ \\
\hline
\end{tabular}


The results obtained in our study demonstrate that the TaqMan assay provides a useful complement to the conventional methods currently used for the detection of Bonamia. It is anticipated that, with wider use of this TaqMan real-time PCR assay, improved surveillance will be achieved, thereby benefitting epidemiological studies, which should lead to improved management and prevention of epizootics in both wild and farmed oysters.

Acknowledgements. This study was partly funded by the Fisheries Research and Development Corporation (Project Number 2003/622). The authors acknowledge Dr. Mike Hine (Ministry of Agriculture and Forestry New Zealand), Dr. Stephen Pyecroft (Department of Primary Industries, Water and Environment, Tasmania) and Dr. Carolyn Friedman (School of Aquatic and Fishery Sciences, University of Washington, USA), as well as Dr. Susan Bower (Pacific Biological Station, BC, Canada) for providing DNA samples of Bonamia-infected and uninfected oysters. The authors thank Dr. Simon Dworjanyn and Mr. Igor Pirozzi (NSW Fisheries) for the collection of wild Ostrea angasi from 5 south coast estuaries in NSW, as well as Maria Lyons from the Marine Institute (Dublin, Ireland) and Marc Engelsma (CIDC, Lelystad, Netherlands) for kindly supplying samples of Ostrea edulis collected in Europe. Haplosporidian material was kindly provided by Dr. Nancy Stokes (Virginia Institute for Marine Science, USA) and Mikrocytos mackini by Dr. Susan Bower (DFO, Pacific Biological Station, Canada). We also thank Mr. Tony Pye (CSIRO Livestock Industries, Australia) for the DNA sequencing and Ms. Donna Jackson for editing the manuscript.

\section{LITERATURE CITED}

Bell TA, Lightner DV (1988) A handbook of normal penaeid shrimp histology. World Aquacultue Society, Baton Rouge, LA

Berthe FCJ, Hine PM (2003) Bonamia exitiosa Hine et al., 2001 is proposed instead of $B$. exitiosus as the valid name of Bonamia sp. infecting flat oysters Ostrea chilensis in New Zealand. Dis Aquat Org 57:181

Berthe FCJ, Burreson EM, Hine M (1999) Use of molecular tools for mollusc disease diagnosis. Bull Eur Assoc Fish Pathol 19:277-278

Burreson EM, Stokes NA, Carnegie RB, Bishop MJ (2004) Bonamia sp. (Haplosporidia) found in nonnative oysters Crassostrea ariakensis in Bogue Sound, North Carolina. J Aquat Anim Health 16:1-9

Campalans M, Rojas P, Gonzalez M (2000) Haemocytic parasitosis in the farmed oyster Tiostrea chilensis. Bull Eur Assoc Fish Pathol 20:31-33

Carnegie RB, Cochennec-Laureau N (2004) Microcell parasites of oysters: recent insights and future trends. Aquat Living Resour 17:519-528

Editorial responsibility: Albert K. Sparks, Seattle, Washington, USA
Carnegie RB, Barber BJ, Culloty SC, Figueras AJ, Distel DL (2000) Development of a PCR assay for the detection of the oyster pathogen Bonamia ostreae and support for its inclusion in the Haplosporidia. Dis Aquat Org 42:199-206

Cochennec N, Le Roux F, Berthe FCJ, Gerard A (2000) Detection of Bonamia ostreae based on small subunit ribosomal probe. J Invertebr Pathol 76:26-32

Cochennec-Laureau N, Reece KS, Berthe FCJ, Hine PM (2003) Mikrocytos roughleyi taxonomic affiliation leads to the genus Bonamia (Haplosporidia). Dis Aquat Org 54: 209-217

da Silva PM, Villalba A (2004) Comparison of light microscopic techniques for the diagnosis of the infection of the European flat oyster Ostrea edulis by the protozoan Bonamia ostreae. J Invertebr Pathol 85:97-104

Diggles BK (2003) NSW flat oyster (Ostrea angasi) disease survey. Final report-November 2003. NIWA Client Report AUS 2003-01. Prepared for NSW Fisheries, NIWA Project NAU 04906, NSW Fisheries, Nelson Bay

Diggles BK, Cochennec-Laureau N, Hine M (2003) Comparison of diagnostic techniques for Bonamia exitiosus from flat oysters Ostrea chilensis in New Zealand. Aquaculture 220:145-156

Dinamani P, Hine PM, Jones JB (1987) Occurrence and characteristics of the haemocyte parasite Bonamia sp. in the New Zealand dredge oyster Tiostrea lutaria. Dis Aquat Org 3:37-44

Farley CA, Wolf PH, Elston RA (1988) A long-term study of 'microcell' disease with a description of a new genus, Mikrocytos (g. n.), and two new species, Mikrocytos mackini (sp. n.) and Mikrocytos roughleyi (sp. n.). Fish Bull 86:581-593

Heasman M, Diggles BK, Hurwood D, Mather P, Pirozzi I, Dworjanyn S (2004) Paving the way for continued rapid development of the flat oyster (Ostrea angasi) farming industry in New South Wales. Final Report to the Department of Transport \& Regional Services Project No. NT002/0195 June 2004, NSW Fisheries Final Report Series No. 66, NSW Fisheries, Nelson Bay

Hine M (1996) Southern hemisphere mollusc diseases and an overview of associated risk assessment problems. Rev Sci Tech Off Int Epizooties 15:563-577

Hine PM, Cochennec-Laureau N, Berthe FCJ (2001) Bonamia exitiosus n. sp. (Haplosporidia) infecting flat oysters Ostrea chilensis (Philippi) in New Zealand. Dis Aquat Org 47:63-72

Howard DW, Smith CS (1983) Histological techniques for marine bivalve molluscs. NOAA Tech Mem NMFS 25:1-97

Kroeck MA, Montes J (2005) Occurrence of the haemocyte parasite Bonamia sp. in flat oysters Ostrea puelchana farmed in San Antonio Bay (Argentina). Dis Aquat Org 63: 231-235

OIE (Office International des Epizooties) (2003) Bonamiosis. Manual of diagnostic tests for aquatic animals 2003, Chapter 3.1.1, 4th edn. OIE, Paris. Also available at: www. oie.int/eng/normes/fmanual/A_summry.htm

Pichot Y, Comps M, Tige G, Grizel H, Rabouin MA (1979) Recherches sur Bonamia ostreae gen. n., sp. n., parasite nouveau de l'huitre plate Ostrea edulis L. Rev Trav Inst Pech Marit 43:131-140

Submitted: April 27, 2005; Accepted: February 10, 2006

Proofs received from author(s): June 16, 2006 